\title{
RELIEF FROM TORT LIABILITY THROUGH REORGANIZATION
}

"I think this is a unique circumstance but not an abuse of the bankruptcy system."1

"I am offended by the perversion of the bankruptcy laws."

Creditors and lenders are not always surprised when one of their debtors files for bankruptcy. Most lenders and creditors regularly estimate the amount of uncollectible accounts in their financial reports. Revenue lost because of debtor bankruptcy is, in a sense, a cost of doing business. Such costs can be limited through careful determination of creditworthiness or by passing on such costs in the form of higher interest charges. The injured party in a tort suit, however, has no similar protection. There is no way for the tort litigant to minimize the chance that the defendant he sues will file for bankruptcy. ${ }^{3}$

The precarious position of the injured plaintiff has become well publicized ${ }^{4}$ in In re Johns-Manville Corp. ${ }^{5}$ In that case, the largest producer of asbestos in America, Manville Corporation, filed for reorganization under chapter 11 of the Bankruptcy Code. ${ }^{6}$ Manville had a $\$ 1.1$ billion net worth and total assets exceeding $\$ 2.2$ billion at the time of filing; ${ }^{7}$ the company was not overextended, nor was it suffering from lagging sales. ${ }^{8}$ Simply, Manville was suffering from thousands of tort actions. ${ }^{9}$

Filing for bankruptcy relief because of massive tort liability is a new phenomenon. A survey of business bankruptcies in six federal

1 N.Y. Times, Aug. 27, 1982, at D4, col. 3 (statement of Ronald Orr, Los Angeles bankruptcy attorney, concerning Manville Corporation petition for reorganization).

${ }^{2} I d$. at A1, col. 6 (statement of Thomas Henderson, Pittsburgh asbestos plaintiffs attorney, concerning Manville Corporation petition for reorganization).

${ }^{3}$ See Note, Tort Claims Under the Present and Proposed Bankruptcy Acts, $11 \mathrm{U}$. Mich. J. L. REF. 417, 417, 435 (1978).

4 See, e.g., Lewin, The Legal Issues in Manville's Move, N.Y. Times, Aug. 27, 1982 , at D4, col. 1 .

B Nos. 82-B-11,656 to 82-B-11,676 (Bankr. S.D.N.Y. filed Aug. 26, 1982).

- 11 U.S.C. $\$ \$ 1101-1174$ (Supp. V 1981).

7 See Stockholders \& Creditors News Serv. Concerning JohnsManvilie CoRP., Et al. 1 (Andrews Publ., Inc.) (Sept. 15, 1982) [hereinafter cited as News SERv.].

Id. at 3,8 .

- Id. at 1. Manville stated that as of June $30,1982,11,000$ suits brought by 15,500 individuals were pending against the company. New suits were being filed at a rate of 425 per month. One projection estimates that Manville could face a total of 52,000 suits and between $\$ 2$ and $\$ 5$ billion in liability before the whole situation has run its course. $I d$. at 3. 
court districts conducted in the late sixties by the Brookings Institution did not even list tort liability as one of the possible causes of business bankruptcy. ${ }^{10}$ Further, as will be discussed later, Congress did not foresee tort liability as a potential cause of bankruptcy when it rewrote the bankruptcy statute in 1978. ${ }^{11}$

The novelty of tort liability as a cause of bankruptcy, however, should definitely not suggest that it will remain an infrequent occurrence. The American environment today is a technologically sophisticated one in which humans have contact with substances whose effects are not yet documented. The toxicity of many substances may go unnoticed for decades because of the state of medical knowledge or the long latency period of a particular disease. Asbestos, for example, has been in use since at least the fifth century B.C., ${ }^{12}$ but the first report on an asbestos-related disease was not made until $1906 .{ }^{13}$ Since that year, the evidence against asbestos has slowly but steadily mounted. ${ }^{14}$ The experience with asbestos is not unique: the miscarriage preventative DES is now known to cause cancer in daughters of women who took the drug and similar claims have been advanced by "DES sons"; the herbicide Agent Orange is also now regarded as carcinogenic, and the toxic materials in industrial waste dumps may prove to be yet another source of deadly disease. ${ }^{15}$ The potential number of suits in such cases is staggering, ${ }^{16}$ and it is reasonable to predict that there will be many more tort defendants seeking bankruptcy in the years to come. ${ }^{17}$

10 D. Stanley \& M. Girth, Bankruptcy: Problems, Process, Reform 111 (1971) (Table 6-2). The study cited "business below expectations" and "internal management problems" as the most common underlying causes of bankruptcy. Id.

11 See infra notes 36-37 and accompanying text.

12 Mehaffy, Asbestos-Related Lung Disease, 16 Forum 341, 342 (1980).

13 Id. at 343 .

14 See id. at 343-45. Today, inhalation of asbestos fibers has been shown to cause a variety of disabling or fatal lung diseases, including asbestosis, mesothelioma, and bronchogenic carcinoma. Id. Asbestosis is a form of pulmonary fibrosis, an abnormal formation of scar tissue following an inflammation in the connective tissue framework of the lungs. Taber's Cyclopedic Medical Dictionary 538 (14th ed. 1981). Mesothelioma is a malignant tumor in the mesothelia surface lining in the lung. Mehaffy, supra note 12, at 344. Bronchogenic carcinoma is the type of lung cancer associated with cigarette smoking. Id. at 343.

There are other diseases, such as cancer of the gastrointestinal tract, which may be related to asbestos exposure. "We have progressed from asbestosis to mesothelioma to bronchogenic carcinoma, and it would not be unrealistic to predict that further progression will take place." Id. at 350 .

16 See Toxic Time Bombs, 67 A.B.A. J. 139, 140 (1981).

${ }^{16}$ More than 1,000 suits have been filed concerning DES and there could be as many as 50,000 plaintiffs in cases involving Agent Orange. Id. at 139-40. Manville Corporation itself may eventually face 52,000 asbestos-related tort actions. See supra note 9.

17 Manville is the second corporation to file for relief because of asbestos litiga- 
The occurrence of bankruptcy due to massive tort liability raises several questions. First, there is the positive question whether the bankruptcy law can be used to help a company whose major creditors are tort claimants. Second, there is the normative question whether the bankruptcy laws should provide such relief. Part I of this Comment discusses the historical treatment of tort claims in bankruptcy proceedings, and shows that although most major reforms of the bankruptcy laws with regard to tort claims have been aimed at improving debtor relief, the treatment of tort claimants has indirectly improved. Part II establishes that the bankruptcy laws can be used as a shield against burdensome tort litigation, and that safeguards exist within the Code to ensure that tort claims are treated equitably and that only debtor-defendants actually in need of bankruptcy relief obtain it. Part III concludes that providing financially distressed tortfeasors with reorganization relief is consistent with the goals of both bankruptcy and tort law, that those underlying policies are best served by allowing the bankruptcy court to consider the claims of future plaintiffs, and that such consideration is not barred by the due process clause.

\section{Historical Treatment of Tort Claims in Bankruptcy Proceedings}

Throughout the course of American bankruptcy law, tort claims have gradually received more comprehensive treatment from Congress. The former Bankruptcy Act, enacted in $1898,{ }^{18}$ embodied the theory that bankruptcy was a relief to be limited to traders. ${ }^{10}$ In England bankruptcy was traditionally concerned only with contractual debt. ${ }^{20}$ Unless reduced to judgments, ${ }^{21}$ tort claims were not considered in liqui-

tion. The first asbestos manufacturer to file was UNR Industries, Inc. See In re UNR Indus., Inc., Nos. 82-B-9841 to 82-B-9851 (Bankr. N.D. Ill. filed July 29, 1982). The third firm to file for chapter 11 relief was Amatex Corporation. See In re Amatex Corp., No. 82-05,220k (Bankr. E.D. Pa. filed Nov. 1, 1982). Because Manville is the largest of the three, the Manville case has engendered the most vociferous and wideranging reactions, as the remarks quoted at the beginning of this Comment demonstrate. Thus, most of the illustrative references in this Comment will be to the Manville proceeding.

18 Bankruptcy Act of 1898, ch. 541, 30 Stat. 544 (codified as amended at 11 U.S.C. $\$ \S 1-1200$ (1976) (repealed 1979)).

10 See Glenn, Basic Considerations in Tort Claims in Bankruptcy and Reorganization, 18 N.Y.U. L.Q. REv. 367, 368-69 (1941).

so Id.

21 When reduced to a judgment, a tort claim was regarded, in "ancient fiction," as a "contract of record." Glenn, supra note 19, at 369. Similarly, quasi-contractual tort claims, such as unjust enrichment, were given consideration in bankruptcy proceedings. Id.; Note, supra note 3 , at 419-20. 
dation proceedings because they were not "provable.",22 Any unprovable tort claim thus could not be discharged by the court. ${ }^{23}$ The knowledge that the defendant would not be freed in bankruptcy proceedings from liability in a pending tort action was small consolation to the tort plaintiff, however, since the eventual result was likely to be an uncollectible judgment.

The reorganization sections ${ }^{24}$ of the 1898 Act similarly ignored tort claims. The focus of those sections of the Act was to provide a "trader" with a means of relief from overwhelming contractual debts. ${ }^{25}$ Thus, a plaintiff in a pending tort action could continue to press his claim in full, any outcome of reorganization notwithstanding. ${ }^{26}$ Reorganization provided the debtor with no relief from tort liability. ${ }^{27}$

The Chandler Act, ${ }^{28}$ enacted in 1938, was a major reform of the Bankruptcy Act which, among other things, provided more comprehensive relief to debtors in reorganizations. The Chandler Act gave the court the authority to consider tort claims in reorganizations, regardless of their provability. ${ }^{29}$ Tort plaintiffs gained such consideration, however, out of congressional concern for the corporation seeking bankruptcy relief, and not out of concern for the plight of tort claimants. Reorganization, as opposed to liquidation, ${ }^{30}$ was designed "to facilitate

22 See Bankruptcy Act of 1898, § 63, 30 Stat. at 562-63 (codified as amended at 11 U.S.C. $\S 103$ (1976) (repealed 1979)).

*3 See id. § 95, as added Apr. 8, 1976, Pub. L. No. 94-260, 90 Stat. 315, 323 (codified as amended at 11 U.S.C. $\S 415$ (1976) (repealed 1979)).

${ }^{24}$ Id. $\$ \S 101-276,301-399$ (codified as amended at 11 U.S.C. $\S \S 501-676$ (1976) (repealed 1979)).

${ }^{25}$ See Glenn, supra note 19 , at 367.

26 Only claims considered by the court in the reorganization proceeding could be discharged. See supra note 23.

$s 7$ One commentator at the time argued that reorganization would fail, at least in the case of railroads, unless the statute protected the interests of tort claimants. Swaine, Federal Legislation for Corporate Reorganization; An Affirmative View, 19 A.B.A. J. 698 (1933).

ss Act of June 22, 1938, ch. 575, 52 Stat. 840 (codified as amended in scattered sections of 11 U.S.C. (1976) (repealed 1979)).

20 The Act achieved this modification by including claims of "whatever character . . . whether or not such claims are provable" in the statutory definition of "claim." Id. sec. 106, 52 Stat. at 883 (codified as amended at 11 U.S.C. $§ 506$ (1976) (repealed 1979)).

so The basic difference between reorganization and liquidation is illustrated by the fact that the Chandler Act did not modify the definition of "claim" in the liquidation chapter to include tort actions, as it did for reorganizations. Almost as soon as the Chandler Act was enacted at least one commentator found the lack of consideration of tort claims in liquidation to be an inexcusable inconsistency given the changes in the reorganization process which allowed tort claims to be considered. See Glenn, supra note 19 , at $372-74$.

There is one exception to the remarks in the text which should be noted. A 1934 amendment provided for consideration of negligence claims in liquidation cases if the suit was pending when the bankruptcy petition was filed. Act of June 7, 1934, ch. 424, 
rehabilitation" of distressed corporations by a "rearrangement of their obligations and shareholders' interests." 31 To succeed, reorganization had to provide "discharge of all demands of whatsoever sort, executory and contingent, presently due or to mature in the future."

The Bankruptcy Reform Act of 1978 constituted a major overhaul of the bankruptcy laws ${ }^{93}$ and continued to permit consideration of pending tort claims in reorganization proceedings. ${ }^{34}$ Congressional attention focused primarily upon modernizing the reorganization process to make it "a quicker, more efficient procedure." the fact that the former reorganization chapters "reflect[ed] a certain lack of sophistication in handling the myriad problems of modern corporate finance."

The House report on the Bankruptcy Reform Act of 1978 describes the nature of the disease for which reorganization was developed as a cure.

The premise of a business reorganization is that assets that are used for production in the industry for which they were designed are more valuable than those same assets sold for scrap. Often, the return on assets that a business can produce is inadequate to compensate those who have invested in the business. Cash flow problems may develop, and require creditors of the business, both trade creditors and long-term lenders, to wait for payment of their claims. If the business can extend or reduce its debts, it often can be returned to a viable state. ${ }^{37}$

sec. 4(a), 48 Stat. 911, 923-24 (codified as amended at 11 U.S.C. $§ 103($ a)(7) (1976) (repealed 1979)). Congress adopted the measure primarily in response to the growing number of suits precipitated by automobile accidents. See J. MacLachlan, HandBOOK OF THE LAW OF BANKRUPTCY $\S 138$ (1956). The failure of Congress to include other types of tort claims, however, further indicates the absence of concern for the general predicament of all tort plaintiffs in bankruptcy proceedings.

31 City Bank Farmers Trust Co. v. Irving Trust Co., 299 U.S. 433, 438 (1937).

82 Id. at 438-39. See also 6 Collier ON BANkRUPTCY 19.05 (14th ed. 1978).

ss See 11 U.S.C. $\$ \S 1101-74$ (Supp. V 1981) (this is the chapter 11 reorganization section). Although much of the new statute which pertains to reorganiźations is contained in chapter 11, many other sections of the statute have general applicability to any bankruptcy action. See id. $\S 103$. For background on the changes the new statute has made and their effects on reorganization, see Downey, Ferriell \& Pfeiffer, The Proposed Bankruptcy Reorganization Provisions: A Comparison of the Current Law with Chapter 11 of H.R. 8200 and S. 2266, 18 SANTA ClaRA L. REv. 567 (1978); King, Chapter 11 of the 1978 Bankruptcy Code, 53 AM. BANKR. L.J. 107 (1979).

See infra notes 40-64 and accompanying text.

s5 H.R. REP. No. 595, 95th Cong., 1st Sess. 5, reprinted in 1978 U.S. CodE Cong. \& AD. NEws 5963, 5966.

s6 Id. at 221, reprinted in 1978 U.S. CoDE Cong. \& AD. News at 6181.

37 Id. at 220, reprinted in 1978 U.S. CoDE ConG. \& AD. News at 6179. 
Thus, reorganization remains oriented toward assisting a company whose poor business performance has placed it in a precarious financial position. Consideration of tort claims remains only incidental to the task of restoring viability to the financially distressed firm. Comprehensive relief requires comprehensive consideration of claims against the debtor, and out of that need, tort claims are allowed a role.

Throughout the congressional deliberations concerning the new bankruptcy code, however, there seems to have been no contemplation of the possibility of bankruptcy caused primarily by tort liability. The issue of whether reorganization relief is nevertheless available to such a debtor is the subject of the following section.

\section{Availability of Chapter 11 Relief TO MASS TORTFEASORS}

\section{A. The Nature of Chapter 11 Relief}

Before considering whether a firm distressed by tort liability can receive chapter 11 protection, it is helpful to discuss briefly what chapter 11 entails and how it handles tort claims. As noted before, the reorganizations chapter is a way to help a financially distressed business return to a viable state. ${ }^{38}$ The goal is “to restructure a business's finances so that it may continue to operate, provide its employees with jobs, pay its creditors, and produce a return for its stockholders." 38 The rationale for providing an alternative to liquidation is that reorganization "is more economically efficient . . . because it preserves jobs and assets." 40 The purpose of the reorganization proceeding is the formulation and acceptance of a plan for restructuring ${ }^{11}$ which establishes the amounts creditors will be paid, the form of payment, the amount of interest to be retained by shareholders, and the form in which the business will continue. ${ }^{42}$ It is the implementation of such a plan that the bankruptcy petitioner seeks from the court. $^{43}$

ss See supra note 31 and accompanying text.

so See H.R. REP. No. 595, supra note 35 , at 220 , reprinted in 1978 U.S. CoDE CoNG. \& AD. NEWS at 6179.

10 Id.

11 Id. at 221, reprinted in 1978 U.S. Code Cong. \& AD. News at 6180.

12 Id. Some commentators have noted that under chapter 11 the question is not whether the business will survive but who will own it. Bulow, Jackson \& Mnookin, Winners and Losers in the Manville Bankruptcy, Wall St. J., Nov. 4, 1982, at 30, col. 3. The authors make this observation by noting that claims against the debtor are often satisfied by payment of securities in the reorganized entity.

13 It should be noted that the petitioner is not always the debtor. Section 303 of the Act allows three creditors with noncontingent claims to petition the court to force reorganization upon a reluctant debtor. 11 U.S.C. $\S 303(b)$ (Supp. V 1981). Such 
The proceeding begins with the filing of the petition which constitutes an automatic order for relief. ${ }^{44}$ The petition automatically institutes a stay of most legal actions which could be pending or initiated against the debtor. ${ }^{45}$ As for tort-related claims, cases pending against the debtor are postponed, new actions cannot be instituted, judgments cannot be recovered, and those seeking subrogation or contribution are forced to wait because of the stay. ${ }^{48}$ The stay itself immediately improves the financial state of the debtor-current obligations are postponed, freeing liquid assets for continuation of the business. ${ }^{47}$

The next step is the establishment of a committee of creditors and, often, a stockholder committee. ${ }^{48}$ The court is also able to appoint, upon request, additional committees should the need arise. ${ }^{40}$ In cases involving a mass tortfeasor, the court might authorize a committee composed of tort plaintiffs. ${ }^{50}$ By bringing together the major creditors and

proceedings are referred to as involuntary, while those initiated by the debtor are known as voluntary reorganizations.

4 Id. § 301.

48 Id. $\S 362(a)$. The stay does not operate to postpone the following: a criminal proceeding against the debtor; the collection of alimony, maintenance, or support from property that is not part of the debtor's estate; an action to perfect an interest in property if the rights of the trustee operating the debtor's business are subject to the perfection; an action by the government to enforce a regulation or a nonmonetary judgment obtained to enforce a regulation; a setoff of a mutual debt based on speculative investments (e.g., futures or forward commodity contracts, leverage transactions, options, warrants, etc.); an action by the Secretary of Housing and Urban Development to foreclose a mortgage or deed of trust held by the Secretary or formerly insured under the National Housing Act involving property of at least five living units; and the issuance of a notice of tax deficiency by the government to the debtor. Id. § 362(b).

${ }^{46} I d . \$ 362(\mathrm{a})(1),(2),(6),(7)$. The stay, of course, does not last forever. The stay of any action against property is lifted if the property in question is disposed of or is otherwise no longer part of the debtor's estate. Id. § 362(c)(1). For the most part, however, the stay continues until the case is closed, dismissed, or until a discharge is granted or denied, whichever is earliest. Id. § 362(c)(2).

Any party in interest may request that the stay be lifted or modified, $i d$. $\S 362$ (d), and the court may grant such relief for cause. Sufficient "cause" in this situation may be limited to interests of secured creditors in the property of the debtor. See, e.g., 124 Cong. Rec. 32,395-96 (1978) (statements of Rep. Edwards) and 124 Cong. Rec. 33,995 (1978) (statements of Sen. DeConcini).

47 For example, after posting a second quarter loss of $\$ 26,158,000$, see NEws SERv., supra note 7, at 3, Manville Corp. rebounded to a third quarter profit of approximately $\$ 24,300,000$. Manville filed for bankruptcy on Aug. 26, 1982, about one month into the third quarter. Manville common stock also rebounded after the slump precipitated by the bankruptcy filing. See N.Y. Times, Nov. 2, 1982, at D10, ed. 3. Most of the turnaround in earnings may have been due to lower operating expenses because of the stay.

411 U.S.C. $\& 1102(a)(1)$ (Supp. V 1981).

10 Id. \& 1102(a)(2).

so Such a committee was formed in the Manville case. In re Johns-Manville Corp., Nos. 82-B-11,656 to 82-B-11,676 (Bankr. S.D.N.Y. Oct. 8, 1982) (order directing the United States Trustee to appoint a committee of asbestos-related litigants and/or creditors), reprinted in Asbestos Litigation Rep. (Andrews Publ., Inc.) 
claimholders the committees provide a structure for consideration of the debtor's situation and development of a reorganization plan. ${ }^{51}$ The debtor has the exclusive right to propose a plan within 120 days from the filing of the petition. ${ }^{52}$ If each class of claims and equity interests has accepted the plan, ${ }^{\text {ss }}$ the court will generally approve the plan. ${ }^{54}$

With regard to classes of claims, the two major categories are typically secured and unsecured claims; ${ }^{.55}$ the statute makes no differentiation between tort claims and other unsecured claims. ${ }^{56}$ Further classification of claims in a plan is subject to a simple rule-the claims in any class must be substantially similar to each other. ${ }^{57}$ Thus, for cases in which a mass tortfeasor is the debtor, the reorganization plan might classify claims as follows: secured claims, debentures, trade credit obligations, and tort claims. The classification is important to the extent that the classification of a claim will determine how it will be treated by the proposed reorganization plan. ${ }^{58}$ All claims within a class must be treated equally. ${ }^{58}$

The power of the reorganization proceeding flows from one particular provision: the so-called "cramdown" provision. ${ }^{60}$ Even if a particular class dissents to and is impaired under the plan, the court may still approve the plan if particular requirements are met regarding the proposed payment to the dissenting class. ${ }^{61}$ Briefly, the court may approve a plan regardless of whether a particular class votes to reject the plan if the claims in the dissenting class will be paid in full. ${ }^{62}$ Alternatively,

5,756 (Oct. 22, 1982). The courts should also appoint a representative to represent the interests of future claimants. See infra notes 105-39 and accompanying text.

s1 See 11 U.S.C. $\S 1103$ (Supp. V 1981).

32 Id. § 1121(b). The court may "for cause" extend the 120-day period. Id. § 1121 (d). If the debtor fails to submit a plan within the allotted time, then a creditor may file a plan. Id. $\S 1121(\mathrm{c})$.

ss Id. \$ 1126.

st Id. § $1129(\mathrm{a})(7),(8)$.

BS Although the statute does not specifically define "unsecured claim," "claim" is defined to include any right to payment whether secured or unsecured, fixed or contingent. Id. $\S 101(4)(\mathrm{A})$. Further, a creditor who has a claim secured by a lien on property of the debtor has a secured claim to the extent of the value of the property which secures the claim. If the collateral's value is less than the amount of the claim, the balance of the claim is unsecured. Id. $\$ 506(\mathrm{a})$. Thus, it seems that all claims which are not secured are unsecured, whether fixed or contingent, whether based on tort or contract law.

See supra note 55 .

s7 11 U.S.C. § 1122(a) (Supp. V 1981).

${ }^{\text {s8 }}$ See id. § 1123(a).

${ }^{50}$ Id. $\S 1123(\mathrm{a})(4)$. A claim may be treated differently from the rest of its class only if the claimholder consents. Id.

${ }^{60}$ See id. § 1129 (b).

61 Id. § 1129(b)(1).

62 See id. $\S 1129(\mathrm{a})(8)$. Basically, a claim is "unimpaired" if the plan provides 
the court may still approve the plan even if the dissenting class will not be paid in full if the plan "does not discriminate unfairly, and is fair and equitable" with respect to such dissenting classes. ${ }^{63}$ An additional prerequisite to court approval is that every holder of a claim must have voted to approve the plan or, if any claimholder rejects the plan, he must receive under the plan an amount equal to what he would receive if the debtor were liquidated. ${ }^{64}$

Thus, the provisions of chapter 11 seek to ensure that the interests of tort claimants, like all claimholders, are adequately protected. Representatives are appointed on behalf of those claimants to approve or reject the proposed reorganization plan. If those representatives vote against the plan, that plan can only be approved by the court if it treats those claimants equitably and does not discriminate against their interests.

With this brief description of the mechanics of reorganization, we can now consider whether tortfeasors can seek chapter 11 relief.

\section{B. Use of Chapter 11 Relief}

Chapter 11 was not originally designed to relieve a debtor suffering from massive tort liability, ${ }^{65}$ and plaintiffs have claimed that such relief should not be available to the asbestos defendants. ${ }^{66}$ Nonetheless,

that the claim will be paid in full. Id. § 1124 .

6s Id. $\S 1129$ (b)(1). Although the requirements that the plan must "not discriminate unfairly" and must be "fair and equitable" may sound simple enough, they really are quite involved. The unfair discrimination provision basically means that equal classes should be treated equally. Because the seniority of one class over another is relative and not absolute, the mechanics of creating a plan that does not discriminate unfairly can become quite complex. See H.R. REP. No. 595, supra note 35, at 416-17, reprinted in 1978 U.S. CoDE CoNG. \& AD. NEws at 6372-73.

The fair and equitable rule is similarly complex. One commentator has described the requirement as follows:

A plan is fair and equitable as to a class of impaired unsecured claims (and therefore the class' acceptance of the plan is not necessary) if the class receives, under the plan, the present value of the full amount of their allowed claims; or, in the alternative, the class receives whatever reorganization values are available after satisfaction of senior classes-and no junior interest receives any reorganization values.

Trost, Business Reorganizations Under Chapter 11 of the New Bankruptcy Code, 34 Bus. LAw. 1309, 1335 (1979) (footnotes omitted)(emphasis in original).

34 11 U.S.C. $\$ 1129$ (a)(7)(A) (Supp. V 1981). The process can become very complex if many claimholders are dissatisfied with the plan. For the court to approve a plan over the objections of a particular "impaired" class, the court has to calculate the value of the debtor's estate so that it can determine whether the dissenting classes will receive an equitable portion of their claims. Such an evaluation can prolong the proceeding by several months.

See supra notes $36-37$ and accompanying text.

${ }^{\circ 8}$ See N.Y. Times, Nov. 9, 1982, at D1, col. 4. 
the statute permits corporate defendants to file for reorganization. ${ }^{67}$ Once the petition is filed, chapter 11 relief may be denied if the court abstains from taking jurisdiction, if the court dismisses the action under section 1112, or if the court determines that the petition was not filed in "good faith." None of these three causes for dismissal, however, should require denial of chapter 11 relief solely because the debtor is a mass tortfeasor.

Courts are free to abstain from taking jurisdiction in any bankruptcy case whenever "the interests of creditors and the debtor would be better served by such dismissal." ${ }^{288}$ The legislative history suggests that the abstention provision is designed to prevent the federal bankruptcy proceeding from duplicating a more feasible out-of-court arrangement. ${ }^{69}$ One court has stated that abstention is proper only under such circumstances. ${ }^{70}$ Thus, the mere fact that a debtor has filed for chapter 11 relief primarily because of excessive tort liability is insufficient reason for a court to abstain from taking jurisdiction. ${ }^{71}$

Section 1112 of the bankruptcy code permits a court to deny chap-

o2 With voluntary petitions, the statute requires only that the petition be filed by "an entity that may be a debtor." 11 U.S.C. § 301 (Supp. V 1981). Any "person" that is not a stockholder or a commodity broker is considered such an entity. Id. $\S 109$ (d). Further, the statute defines "person" to include a corporation. Id. $\S 101(30)$. Thus, any incorporated manufacturing concern, such as the asbestos defendants, may file for chapter 11 relief.

Id. § 305(a)(1).

oo The legislative history states:

The court may dismiss ... , for example, if an arrangement is being worked out by creditors and the debtor out of court, there is no prejudice to the rights of creditors in that arrangement, and an involuntary case has been commenced by a few recalcitrant creditors to provide a basis for future threats to extract full payment. The less expensive out-of-court workout may better serve the interests in the case.

H.R. REP. No. 595, supra note 35, at 325, reprinted in 1978 U.S. Code CoNG. \& AD. News at 6281. See, e.g., In re Nina Merchandise Corp., 5 Bankr. 743 (Bankr. S.D.N.Y. 1980); In re Luftek, Inc., 6 Bankr. 539 (Bankr. E.D.N.Y. 1980).

${ }^{70}$ In re WPAS, Inc., 6 Bankr. 44 (Bankr. M.D. Fla. 1980). But cf. In re Fast Food Properties, Ltd., 5 Bankr. 539 (Bankr. C.D. Cal. 1980) (suggesting abstention is proper whenever a case imposes upon the jurisdiction of the court).

"1 A situation may arise in which congressional action would create a mandatory tort victim compensation system, replacing individual tort suits. The proposed Occupational Health Hazards Compensation Act of 1982, H.R. 5735, 97th Cong., 2d Sess. (1982), for example, would provide for the compensation of individuals who are disabled as a result of occupational exposure to asbestos or uranium ore.

While it may be argued that in a given situation, such as the asbestos litigation, legislative solutions may be optimal from society's standpoint, the mere consideration by Congress of any such compensation system should not automatically cause a bankruptcy court to abstain. Bills do not always become laws, and the problems of corporate mass tortfeasors and potentially uncompensated future claimants are all too real. See infra text accompanying notes 124-28 and 137-39. 
ter 11 relief" to a petitioner "for cause." ble situations which would constitute cause, including reasonable likelihood that the debtor cannot be rehabilitated and difficulties in effectuating a plan. ${ }^{74}$ None of the listed situations ${ }^{75}$ require dismissal solely because the debtor is a tort defendant; rather, the court must consider the facts of each case and determine what is "in the best interest of creditors and the estate."'78

Finally, a court may dismiss a petition for reorganization if it determines that the petition was not filed in good faith. ${ }^{77}$ Requisite good faith has been deemed lacking in cases in which reorganization was impossible, ${ }^{78}$ in which the debtor was unwilling to effectuate a reorgan-

72 The court may either convert the case to a chapter 7 liquidation case or dismiss the case altogether. 11 U.S.C. $\S 1112$ (b) (Supp. V 1981). Within certain limits, a debtor may also convert a case to a chapter 7 case. See id. $\S 1112(a)$.

78 Id. § 1112(b).

74 Those situations are:

(1) continuing loss to or diminution of the estate and absence of a reasonable likelihood of rehabilitation;

(2) inability to effectuate a plan;

(3) unreasonable delay by the debtor that is prejudicial to creditors;

(4) failure to propose a plan under section 1121 of this title within - any time fixed by the court;

(5) denial of confirmation of every proposed plan and denial of additional time for filing another plan or a modification of a plan;

(6) revocation of an order of confirmation under section 1144 of this title, and denial of confirmation of another plan or a modified plan under section 1129 of this title; plan;

(7) inability to effectuate substantial consummation of a confirmed and

(8) material default by the debtor with respect to a confirmed plan;

(9) termination of a plan by reason of the occurrence of a condition specified in the plan.

Id. Many of these causes result in a conversion of the action into chapter 7 proceedings.

78 It should be noted that the list in note 74 is not exhaustive. Section $1112(\mathrm{~b})$ cites the reasons for cause as "including" those nine situations, and "including" is to be construed as not limiting. Id. $\S 102(3)$. The legislative history notes that the "court will be able to consider other factors as they arise, and to use its equitable powers to reach an appropriate result in individual cases." H.R. REP. No. 595, supra note 35, at 406, reprinted in 1978 U.S. CoDE CONG. \& AD. NEwS at 6362.

7611 U.S.C. $\S 1112$ (b) (Supp. V 1981).

77 The Bankruptcy Act of 1898 required that petitions for reorganization be filed in good faith. See Bankruptcy Act of $1898 \S 141,52$ Stat. 840, 887 (codified as amended at 11 U.S.C. $\$ 541$ (1976) (repealed 1979)). Courts interpreting the Bankruptcy Reform Act of 1978 have stated that although the Code no longer explicitly requires good faith in filing petitions for reorganization, good faith is nevertheless "an implicit prerequisite" to relief. E.g., In re Victory Const. Co., Inc., 9 Bankr. 549, 558 (Bankr. C.D. Cal. 1981).

78 See, e.g., In re Western Tool \& Mfg. Co., 142 F.2d 404 (6th Cir. 1944), rev'd on other grounds, 324 U.S. 100 (1945). 
ization, ${ }^{79}$ or in which the petition was filed for purposes other than reorganization, such as for the preservation of assets. ${ }^{80}$ Good faith has never been found lacking solely because the bulk of a petitioner's creditors were tort plaintiffs. ${ }^{81}$ Plaintiffs in the Manville proceeding, however, have claimed that the asbestos manufacturer did not file for reorganization in good faith, that the firm is seeking only to escape liability to the asbestos victims. ${ }^{82}$

A determination that a mass tortfeasor has filed for reorganization solely to escape liability will require a finding that the firm is able to satisfy its tort obligations; a mere showing that the debtor-petitioner is currently solvent is insufficient to dismiss for lack of good faith. ${ }^{83}$ In cases involving latent injury, where the disease may not manifest itself for over thirty years, ${ }^{84}$ an accurate determination of a debtor's liability may be extremely difficult. Not only is most of the debtor's liability contingent and unliquidated in such cases, but it is also difficult even to determine the total number of claims against the company seeking relief $^{\mathrm{sb}}$ This estimation of the debtor's liability is a factual determination to be made by the court, ${ }^{86}$ and once made, only then can the court

79 See, e.g., Leatherhide Indus., Inc. v. Lieberman, 268 F.2d 206 (2d Cir. 1959), cert. denied, 361 U.S. 896 (1959).

${ }_{80}$ See, e.g., In re Nancant, Inc., 8 Bankr. 1005 (Bankr. D. Mass. 1981) (petition filed solely to have tax liability determined); In re Fast Food Properties, Ltd., 5 Bankr. 539 (Bankr. C.D. Cal. 1980) (petition filed solely to frustrate a power of sale provision under a deed of trust); In re G-2 Realty Trust, 6 Bankr. 549 (Bankr. D. Mass. 1980) (petitioner changed the form of its entity solely to be eligible under chapter 11 in order to prevent foreclosure).

81 In one case, the court found a tort-besieged debtor to have met the requirement of good faith. See In re Alton Tel. Printing Co., 14 Bankr. 238 (Bankr. S.D. Ill. 1981). In Alton the debtor was a newspaper company which had lost a $\$ 9.2$ million libel suit. The newspaper was unable to post a supersedeas bond (required in order to appeal the libel judgment) without filing under chapter 11 to obtain a stay.

82 See Application for Dismissal of Cases or Abstention, In re Johns-Manville Corp., Nos. 82-B-11,656 to 82-B-11,676 (Bankr. S.D.N.Y. filed Aug. 26, 1982); see supra note 66.

8s The previous Code did require that the petitioner be insolvent. Bankruptcy Act of $1898 \S 130$ (codified as amended at 11 U.S.C. $\S 530$ (1976) (repealed 1979)) (requirements for a former chapter X reorganization); id. $\$ 323$ (codified as amended at 11 U.S.C. $\$ 723$ (1976) (repealed 1979)) (requirements for a former chapter XI arrangement). Why the insolvency requirement was dropped is unclear. The legislative history of the new statute makes no reference to the old "insolvency" requirement.

se Statutes of Limitation Eased to Permit Latent Disease Claims, 11 ENvTL. L. ReP. (ENvTl. L. Inst.) 10,082 (Mar. 4, 1981).

${ }^{85}$ For example, in the Manville case, there were 11,000 tort suits against the company when it filed for relief. See supra note 9 . Moreover, projections of the total number of asbestos tort actions against Manville suggest that as many as 50,000 suits will eventually be filed. $I d$.

${ }_{\text {se }}$ See 11 U.S.C. $\$ 502$ (c) (Supp. V 1981). One commentator has suggested that the bankruptcy court should estimate Manville's aggregate asbestos-related liability, and leave the estimation of individual claims to state courts and other federal courts. 
determine if the corporate defendant filed without good faith.

Thus, the bankruptcy laws permit corporate tortfeasors to file for reorganization. If, however, the court determines that the debtor does not actually require such relief (because, for example, the debtor overestimated its liability), or that the petitioner is merely attempting to limit its tort liability, the court is free to dismiss the petition for lack of good faith. Concluding that reorganization relief is available to corporate defendants raises the normative question of whether such relief should be available.

\section{The Appropriateness of Bankruptcy Relief for MASS TORTFEASORS}

\section{A. Bankruptcy Relief for Mass Tortfeasors Furthers the Goals of Bankruptcy and Tort Law}

It has been shown thus far that the statutory provisions and equitable doctrines of bankruptcy law permit financially distressed tortfeasors to file for and receive bankruptcy relief. Granting such relief, particularly chapter 11 reorganization relief, advances the goals of both bankruptcy and tort law.

The bankruptcy laws serve two functions. The oldest form of bankruptcy relief, liquidation, was "established to resolve in a fair and orderly manner the conflicts in interest that arise among creditors of a debtor who cannot pay his debts"; ${ }^{87}$ it prevents creditors from racing to the courthouse, each seeking to satisfy his claims against the debtor before the depletion of the debtor's assets. Reorganization incorporates this goal and adds another policy consideration: since a business's assets usually have more value when they form a going concern than if sold for scrap, it is generally more economically efficient to rehabilitate than to liquidate a debtor. ${ }^{88}$

It is much more difficult to give a concise statement of the goals of tort law. ${ }^{89}$ Although many purposes and rationales for tort relief can be

Note, The Manville Bankruptcy: Treating Mass Tort Claims in Chapter 11 Proceedings, 96 HaRv. L. REv. 1121, 1128-41 (1983). It is not clear that this is necessarily an equitable result. The author notes that "[i]n the 3500 suits that Manville disposed of before its chapter 11 filing, its total defense costs were nearly equal to the total cost of the judgments rendered against it." Id. at 1129 n.44. Forcing Manville to continue defending suits in various courts would place a heavy burden on the company, and would necessarily deplete the assets available to the tort claimants. Thus, if the bankruptcy court were to appoint masters to estimate the value of individual claims, for example, both the claimants and debtor would be benefited.

${ }_{87}$ D. STANLEY \& M. GiRTH, supra note 10, at 9.

so See supra note 37 and accompanying text.

80 Part of the problem is that no satisfactory definition of "tort" exists. Prosser 
proffered, ${ }^{80}$ it is sufficient to state that at a minimum tort law is designed both to compensate victims and to deter at least some future injurious conduct.

Permitting mass tortfeasors to receive bankruptcy relief is consistent with these goals. Bankruptcy proceedings permit the court to consider all the tort claims against the debtor: those that have been reduced to judgments, those pending, and those which have yet to be filed.pr This consideration of all the claims together permits an orderly treatment of all the plaintiffs, and prevents plaintiffs who receive prior judgments from obtaining significantly higher awards than those who receive later judgments. ${ }^{92}$ At the same time, this collective treatment prevents any plaintiffs from receiving total compensation for their injuries from the debtor. The tort law goal of compensation is better served, however, by allowing all the injured an equitable share of the debtordefendant's assets. ${ }^{93}$ Further, although there may be due process problems occasioned by the bankruptcy court's consideration and estimation of the compensation of a victim who has yet to file a tort claim against the debtor-defendant, these difficulties are not insurmountable, as will be discussed below.94

begins his famous hornbook by pointing out the peculiar lack of coherence which exists in the law of torts:

Included under the head of torts are a miscellaneous group of civil wrongs, ranging from simple, direct interferences with the person, such as assault, battery, and false imprisonment, or with property, as in the case of trespass or conversion, up through various forms of negligence, to disturbances of intangible interests, such as those in good reputation, or commercial or social advantage. These wrongs have little in common and appear at first glance to be entirely unrelated to one another, except perhaps by the accident of historical development; and it is not easy to discover any general principle upon which they may all be based, unless it is the obvious one that injuries are to be compensated, and antisocial behavior is to be discouraged.

W. Prosser, The Law of Torts 2-3 (4th ed. 1971).

${ }^{20}$ See generally id. at 16-23.

91 See infra text accompanying notes 105-14.

92 "Because bankruptcy eschews a first-come, first-served payment system, the existing claimants stand to lose; the future claimants stand to gain." Bulow, Jackson \& Mnookin, supra note 42 , at col. 5 .

${ }_{93}$ A recent study concluded that if all asbestos victims are allowed to continue receiving full compensation for their injuries, as the earliest plaintiffs have, the result will be the bankruptcy of the corporate defendants and their insurance companies. Thus, not only would future asbestos claimants be without compensation, but policyholders besides product liability insurance holders would lose their coverage and be exposed to uninsured losses. See P. MacAvoy, The Economic Consequences of Asbestos-Related Disease 85-86 (Jan. 1982) (Series C-Research Program in Government Business Relations, Yale School of Organization and Management, Working Paper No. 27) (copy on file at University of Pennsylvania Law Review).

o4 See infra notes 130-39 and accompanying text. 
It may be argued that the tort law goal of preventing future injurious conduct will be frustrated if mass tortfeasors are permitted bankruptcy relief because the debtor will not have to compensate the victims fully for their injuries; ${ }^{95}$ some of the debtor's liability will be shifted to its creditors. This argument is unpersuasive, however, for several reasons. First, the cost of even partially compensating tens of thousands of victims would be staggering. ${ }^{96}$ There is little likelihood of the tortfeasor paying for all its tortious conduct even without reorganization. Second, even though the debtor may be relieved from fully compensating each victim, bankruptcy proceedings have consequences for the debtor sufficiently drastic to deter future injurious conduct. If the debtor is liquidated, the corporation is dissolved and the shareholders will lose their investment. ${ }^{97}$ Even if the debtor is able to survive reorganization, there is a strong possibility that ownership of the corporation will be in new hands. ${ }^{98}$ These severe consequences should provide a sufficient deterrent effect. Also, to argue that deterrent value is lost when the debtor is able to shift some liability to its creditors is to ignore the realities of corporate cost shifting. Most often the costs of liability do not come totally from the firm's profits, but are passed on to customers in the form of higher product prices. ${ }^{99}$ Making trade creditors or institutional lenders bear part of the cost of liability is but another form of distributing these costs. ${ }^{100}$ It is possible that those creditors will bring pressure

95 See supra note 93 and accompanying text. The probability is that many cases will arise in which a mass tortfeasor simply does not have enough assets to compensate its victims. See supra note 16 . While the policy behind chapter 11 suggests that a reorganization plan should include a payment schedule that leaves the debtor with sufficient assets to attempt to continue as a going concern, see supra text accompanying note 37 , the fund provided for tort claimants in that plan must be large enough to enable each victim to receive an amount that bears some reasonable relationship to the actual damages incurred. Otherwise, the argument that the bankruptcy system offers the most equitable method of dealing with present and future plaintiffs loses much of its force. How much is enough-but not too much-is, of course, the essential question. One commentator suggests a sum including an estimation of the cost of insurance sufficient to cover all those significantly more likely to sustain future injury than members of the general public. See Comment, Procedures for Estimating Contingent or Unliquidated Claims in Bankruptcy, 35 STaN. L. Rev. 153, 172 (1982).

- See supra note 9 and accompanying text.

o7 In liquidation, the claims of all creditors are satisfied before the claims of equityholders. See 11 U.S.C. § 726 (Supp. V 1981).

- See supra note 42 and accompanying text.

- Indeed, this ability to pass on the cost of liability is one of the reasons for the rise of liability without fault, a policy which allows more frequent recovery by tort victims. See W. Prosser, supra note 89 , at 22.

200 In general, the passing on of such costs would probably result in higher interest rate charges as lenders attempt to pass on the added cost of losses due to tortfeasor reorganization. In turn, borrowers who must pay the resulting higher rates would be likely to pass on the increased cost to their customers which, in effect, is an outcome equivalent to that resulting from the average tort liabilty. Moreover, borrowers who 
on their debtor (the potential tortfeasor) to take care to avoid large tort liabilities.

Finally, although permitting financially distressed tortfeasors some form of bankruptcy relief will not violate the purposes behind the bankruptcy and tort laws, it should be noted that those purposes will be better advanced through the use of reorganization rather than liquidation. First, if the bankruptcy courts determine that the interests of future claimants cannot be considered in bankruptcy proceedings, ${ }^{101}$ successful reorganization will ensure that a defendant exists when those claims do become justiciable. Second, reorganization may make more assets available for compensating victims. Creditors can agree to delay demands upon the debtor, and the plan could shift losses to trade creditors who might otherwise have been paid off in full. ${ }^{102}$ As some commentators have argued, reorganization allows the collectivization of the tort claims which promotes summary disposition of the claims and saves litigation costs. ${ }^{103}$ Finally, as noted above, ${ }^{104}$ reorganization in general is more economically efficient than liquidation for it preserves the debtor as a going concern.

\section{B. Considering the Future Claims in the Reorganization Plan}

\section{Considering Future Claims is Permitted by the Statute}

The debtor-defendants in the asbestos litigation have argued that a successful reorganization of their companies can be effected only if the reorganization plan considers the claims of the victims whose asbestosrelated injuries have yet to surface. ${ }^{105}$ Although such treatment of future claimants raises novel legal issues, consideration of those claims in the reorganization plan is permitted by the statute and serves the twin goals of compensating the claimants and rehabilitating the debtor.

For a claim against a debtor to be discharged through reorganization, proof of that claim must be filed with and allowed by the court. ${ }^{108}$

run a higher risk of massive tort liability would probably have to pay the highest rates. Thus, it is likely that by passing on such extra costs to customers, the prices of products that carry a high risk of injury will be more representative of the true cost of such products.

${ }_{101}$ See infra notes 105-39 and accompanying text.

102 See Bulow, Jackson \& Mnookin, supra note 42.

10 Id., at col. 4.

104 See supra note 37 and accompanying text.

108 "This isn't some Alice-in-Wonderland theoretical game we're dealing with. . . We're talking about money. If we don't get those unknown claims defined and allowed, it won't be there." Wall St. J., Mar. 16, 1983, § 2, at 33, col. 5 (statement of Malcolm Gaynor, attorney for asbestos debtor-defendant UNR Industries, Inc.).

${ }_{108} 11$ U.S.C. § 523(a)(3) (Supp. V 1981). 
The debtor is required to file with the court a list of its creditors and their claims. ${ }^{102}$ All listed claims are deemed filed with and allowed by the court, ${ }^{108}$ except those which are disputed, unliquidated, or contingent. ${ }^{109}$ Thus, the claims of successful plaintiffs which have been reduced to judgments are fixed, liquidated, and thereby deemed filed and allowed.

Less clear is the statute's treatment of contingent and unliquidated claims. The statute provides that the confirmation of a reorganization plan "discharges the debtor from any debt that arose before the date of such confirmation."110 "Debt" is defined as "liability on a claim,"111 and "claim" includes a "right to payment, whether or not such right is reduced to judgment, liquidated, unliquidated, fixed, contingent, matured, unmatured, disputed, undisputed, legal, equitable, secured, or unsecured."112 The legislative history states that "[b]y this broadest possible definition [of 'claim'] . . . the bill contemplates that all legal obligations of the debtor, no matter how remote or contingent, will be able to be dealt with in the bankruptcy case. It permits the broadest possible relief in the bankruptcy court."113 The statute also provides that contingent and unliquidated claims may be allowed by the court through an estimation of those claims. ${ }^{114}$ It appears, therefore, that through the use of the estimation provision the statute permits the bankruptcy court to discharge the claims of future plaintiffs.

Despite this broad language of the statute and legislative history, the first court to consider the rights of future claimants in the reorganization of a financially distressed tortfeasor has held that the claims of future plaintiffs can not be discharged through reorganization. District Judge William Hart denied the application of chapter 11 debtor-defendant UNR Industries, Inc. for the appointment of a legal representative for unknown future asbestos claimants. ${ }^{115}$ Judge Hart decided that future claimants are not encompassed by the Bankruptcy Code which defines a creditor as a person "who has a claim against the debtor that

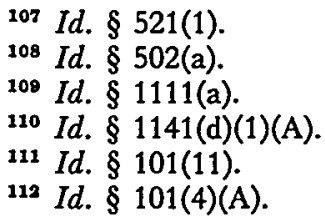

11 H.R. REP. No. 595, supra note 35, at 309, reprinted in 1978 U.S. CoDE CoNG. \& AD. NEwS, at 6266 (emphasis added).

11411 U.S.C. § 502(c) (Supp. V 1981). See supra note 86 and accompanying text.

${ }_{118}$ In re UNR Indus., Inc., Nos. 82-B-9841 to 82-B-9851 (Bankr. N.D. Ill. Mar. 25, 1983) (order denying debtor's "Application for the Appointment of a Legal Representative for Unknown Putative Asbestos-Related Claimants"). 
arose at the time of or before an order for relief."116 Since asbestos plaintiffs do not have a cognizable claim against the debtor under state law until the plaintiffs know or should know about their injury, by definition future plaintiffs can not currently have such a claim. ${ }^{117} \mathrm{Be}-$ cause future plaintiffs have no claim under state law, Judge Hart held they also have no claim recognized by the bankruptcy law and no interests which would require the appointment of legal representation. ${ }^{118}$

The judge narrowly interpreted a contingent claim as "one that arises out of the prior contractual relationship of the claimant and debtor,"118 and added that the "legislative history does not support the contention that the term 'contingent' is intended to encompass a common law tort action which might arise in the future."120 In any case, the Code's reference to the estimation of a contingent claim did not alter the basic definition of a claim. Thus Judge Hart concluded that solutions to the problems of the future claimants must come from Congress, because "[t]here is simply no authority in the statute or Constitution for this Court to grant the debtors the relief they seek."121

Judge Hart's opinion is unpersuasive for several reasons. First, its undue emphasis on the Code definition of creditor ignores the argument that a future plaintiff's "right to payment" actually arose at the time of tortious conduct: exposure to the hazard. ${ }^{122}$ Second, the judge's narrow view of contingent claims seems at odds with the statutory language, and relevant legislative history, permitting a court to consider all legal claims, no matter how remote, unliquidated, or contingent. ${ }^{123}$

The decision reached by Judge Hart is also disturbing because it is inimical to the purposes of reorganization relief. As noted above, ${ }^{124}$

${ }^{110}$ See 11 U.S.C. § 101(9) (Supp. V 1981).

${ }^{117}$ In re UNR Indus., Inc., Nos. 82-B-9841 to 82-B-9851, slip op. at 9 (Bankr. N.D. Ill. Mar. 25, 1983).

${ }_{118}$ Id. at 9-12. Judge Hart also noted that it would be impossible for one legal representative to represent adequately the claims of all future claimants, id. at 14, and that the problems of notifying those whom the representative's action would bind would be insurmountable, id. at 15. See infra notes 130-39 and accompanying text.

119 Id. at 9-10 (emphasis in original). But see infra note 123.

$120 \mathrm{Id}$. at 11 n.4.

121 Id. at 18.

122 See Note, supra note 86, at 1131 n.52; $c f$. Keene Corp. v. Insurance Co. of N. Am., 667 F.2d 1034 (D.C. Cir. 1981) (insurance policies covering exposure of workers to asbestos are triggered by exposure as well as by manifestation of disease), cert. denied, 455 U.S. 1007 (1982). But see Fusco v. Johns-Manville Prods. Corp., 643 F.2d 1181 (5th Cir. 1981).

${ }_{123}$ See supra notes 111-14 and accompanying text. A leading treatise defines contingent claims as debts that, either as to their existence or as to their amount, depend upon some future event uncertain either as to its occurrence altogether or as to the time of the occurrence. 3A ColliER ON BANKRUPTCY $\S 63.30$, at 1912.1 (14th ed. 1977).

${ }^{124}$ See supra note 88 and accompanying text. 
reorganization is designed to aid and restore financially insecure businesses; it is more economically efficient to reorganize than to liquidate. The asbestos defendants have argued that unless they are allowed to consider the tens of thousands of future claims, they will be forced to liquidate because trade creditors and lending institutions will refuse to do business with a company facing such tremendous liability. ${ }^{125}$ At least one asbestos defendant has been liquidated, ${ }^{126}$ and unless some relief is granted, more will follow. ${ }^{127}$ For the bankruptcy courts to refuse to consider the future claims and to abdicate their role in fashioning relief, a course Judge Hart suggests, ${ }^{128}$ is an inadequate reply; ${ }^{128}$ it fails to recognize that the bankruptcy courts have the equitable powers to consider the future claims.

\section{Due Process Does Not Bar Consideration of Future Claims}

Since inclusion of the claims of future plaintiffs in a reorganization plan through the appointment of a legal representative may reduce or eliminate the value of those claims, due process considerations are clearly implicated by such a plan. ${ }^{130}$ In In re UNR, Judge Hart found that the problems of notifying those whom the legal representative would be able to bind were insurmountable, ${ }^{131}$ and thus the plan of reorganization would be subject to constant attacks over the years on due process grounds. ${ }^{\mathbf{1 3 2}}$

Such a view, however, is less than imaginative and not mandated by the Constitution. Supreme Court precedent exists for the proposition that adjudications concerning a limited fund may proceed despite the absence of beneficiaries whose identity and whereabouts are unknown, provided that a guardian for their interests is appointed. In Mullane $v$. Central Hanover Bank $\mathcal{E}$ Trust Co., ${ }^{138}$ a guardian for the interests of

${ }^{128}$ See Wall St. J., Mar. 16, 1983, § 2, at 33, col. 4.

128 Forty-Eight Insulations, Inc. sold off all of its operating assets as a going concern for cash and is paying off asbestos claims until the cash is gone. See Bulow, Jackson \& Mnookin, supra note 42.

127 See P. MacAvoy, supra note 93, at 85-86.

188 See In re UNR Indus., Inc., Nos. 82-B-9841 to 82-B-9851, slip op. at 18 (Bankr. N.D. Ill. Mar. 25, 1983). For competing views on the form that the congressional action should take, see Miller, Don't Let Industry Shirk Its Duty, N.Y. Times, Sept. 5, 1982, § 3, at 2, col. 3; Hart, Let Govermment Bear its Share, id. at col. 5; see also supra note 71 .

126 See supra notes $71 \& 126$.

130 See Comment, supra note 95, at 161.

131 In re UNR Indus., Inc., Nos. 82-B-9841 to 82-B-9851, slip op. at 15 (Bankr.

N.D. Ill. Mar. 25, 1983).

$182 \mathrm{Id}$. at 17.

133339 U.S. 306 (1950). 
unascertained beneficiaries was appointed to confirm or object, at the annual accounting, to the procedures followed by the trustee in managing a trust fund. The guardian's confirmation of the trustee's procedures would serve to "cut off" the rights of the unascertained beneficiaries "to have the trustee answer for negligent or illegal impairments of their interests." 194 The Court went on to hold that this right was sufficiently protected by notice through publication to the unknown beneficiaries, since there was already a guardian appointed to protect their interests. ${ }^{135}$ Although in the asbestos cases the persons who eventually will become claimants do not now know they will become claimants, they do know that they are members of a clearly defined class of potential claimants, namely workers who were exposed to asbestos. Reasonable notice to those potential claimants should satisfy the requirements of Mullane. Thus, it would seem constitutionally permissible to bind future asbestos claimants now and prevent them from pursuing claims against the debtor later, provided that a representative is appointed to protect their interests. ${ }^{198}$

Finally, failing to consider the future claimants now can only have disastrous consequences for those claimants later. The notice required by due process seeks to protect the interests of future claimants; an inflexible application of those requirements would work the reverse. ${ }^{137}$ As Judge Hart acknowledged, "The Court is not unaware that in refusing to approve of a procedure by which the rights of the putative claimants would be adjudicated and cut off, the putative claimants may wind up with judgments against corporations left with only one asset: a corporate charter." ${ }^{\text {138 }}$ Refusing to consider now the claims of future victims may prevent them from ever receiving any compensation from the debtor. Such a result, certainly detrimental to the goals of tort law, should not be considered constitutionally mandated. As one commentator has stated, "the due-process clause has never been construed to re-

134 Id. at 313 .

$128 \mathrm{Id}$. at 317 .

136 This argument based on Mullane has been advanced by asbestos debtor-defendant Amatex Corporation in its efforts to have the court appoint a guardian ad litem to represent its future claimants. See Brief of Amatex Corporation, Debtor in Possession, Objecting to the Relevance of Mr. Greitzer's Proffered Testimony, at 6-11, In re Amatex Corp., No. 82-05,220K (Bankr. E.D. Pa. filed Nov. 1, 1982). In that brief, Amatex argued against the admission of testimony that in most jurisdictions a cause of action for tort does not arise until an injury becomes manifest.

137 "It has been said so often by this Court and others as not to require citation of authority that due process is flexible and calls for such procedural safeguards as the particular situation demands." Morrissey v. Brewer, 408 U.S. 471, 481 (1971).

${ }^{138}$ See In re UNR Indus., Inc., Nos. $82-\mathrm{B}-9841$ to $82-\mathrm{B}-9851$, slip op. at 18 (Mar. 25, 1983). 
quire the impossible. This may be the best the courts can do."139

\section{CONCLusion}

Although not designed to relieve tortfeasors from the financial stress of massive liability, the bankruptcy reorganization laws nevertheless provide the flexibility necessary to achieve an equitable solution which preserves the interests of both the claimants and the debtor. First, if the court determines that the tortfeasor is inaccurately estimating its potential liability and is merely using reorganization to escape liability, the court can dismiss the debtor's petition for lack of good faith. Second, the appointment of a tort plaintiffs' committee ensures that the claimants' rights will be adequately protected. That committee has the power to approve or reject a proposed reorganization plan; if the court nevertheless approves a rejected plan, the statute requires that the plan not discriminate unfairly among the claimants and that it be fair and equitable. Finally, the statutory language and legislative history of the bankruptcy code indicate that the court can appoint a guardian to represent the interests of future claimants. Such a step is constitutionally permissible and would serve the dual goals of ensuring that those claimants will receive at least some compensation for their injuries, and that the debtor corporation can successfully reorganize and return a viable company.

139 See Wall St. J., March 16, 1983, §2, at 33, col. 5 (statement of Professor Vern Countryman, Harvard Law School). In concluding that the special circumstances of the future claimants may require a less restrictive view of due process, it should be noted that some traditional rules of due process are more relaxed in bankruptcy courts. Cf. In re DCA Development Corp., 489 F.2d 43, 46 (1st Gir. 1973) (individual's interest in notice and hearing must be balanced against the overall interest in efficient, final resolutions of claims; latter interest is particularly important in bankruptcy context) (applying former bankruptcy act). For example, tort litigants generally have no right to a jury trial in the bankruptcy court; this would apply to the asbestos plaintiffs pursuing claims against debtor-defendants. See Note, supra note 86, at 1140-41. 
